\title{
MANIFESTATION OF ETHNICITY AND VALUES: THE CASE STUDY FROM THE EASTERN LATVIA
}

\author{
Valērijs Makarevičs \\ Daugavpils University, Latvia \\ Dzintra Iliško \\ Daugavpils University, Latvia
}

\begin{abstract}
Values has been explored in connection to a deeper understanding of human behavior. Values provide the answer to the basic existential questions, help to provide meaning in one's life. Values are the key aspects of one's self-esteem. They reflect diverse aspects of one's social identity. According to a number of scientists, ethnic identity is a part of social identity. A number of studies in psychology has a focus on the connection between ethnicity and ethnic values. There are two main approaches towards the study of values can be distinguished. On the one hand, there are values that have the existential basis for the existence of people. On the other hand, the information about ethnic values can have applied aspect. The aim of this study is to identify differences in value orientation among representatives of two main linguistic groups that live in Eastern Latvia: the group of Latvian and Russian-speaking participants. The second goal is to explore the influence of religion, age and gender on the values of the research participants. The methodology used for the purpose of this study was to determine value orientation towards family, religious and friendship. The authors discovered statistically significant differences only in relation to a value of friendship. This value turned out to be the highest among the Russian-speaking group as compared to the Latvian-speaking group, as well as in the Orthodox group as compared to the group of Catholics.
\end{abstract}

Keywords: Eastern Latvia, ethnic identity, religion, religious affiliation, value.

\section{Introduction}

Values in the social sciences can be explored in connection to understanding of a human behavior, especially in cases where behavior is not determined only by the biological needs. According to D. Karp, values provide an answer to the basic existential questions by helping to give meaning for people's lives (Karp, 2020). Therefore, people's values determine common aspirational goals, which, in turn, motivate their actions and serve as guiding principles in their lives (Anýžová, 2017; Kluckhohn, 1951; Meeussen, Agneessens, Delvaux, Phalet, 2018). Individual's behavior can be ambivalent in terms of values; they can serve more than a motivational purpose. In such cases, people with different value 
Makarevičs \& Iliško, 2021. Manifestation of Ethnicity and Values:

the Case Study from the Eastern Latvia

priorities can behave in the same way. This leads to the inconsistent relationship between values and behavior (Sagiv, Roccas, Cieciuch \& Schwartz, 2017).

However, multiple ethnic values may motivate certain ethnic behavior. For example, representatives of ethnic groups may be motivated to participate in their own ethnic festivals as quidded by values of their ethnic engagement, ethnic awareness and/or ethnic heritage. Moreover, some ethnic behaviors express ethnic values more than other values (Jugert, Titzmann, 2020; Yang, Liang, Quan, Jiang, $\mathrm{Yu}$, Zheng, 2019). The variability of behavior can be explained by the degree of generalization of values. The higher is the degree of generalization of values, the more varied and selective is their influence on one's behavior. Thus, people may see equality as relevant in situations of ethnic or gender diversity, but they may not see it in relation as relevant to a weight discrimination (Cieciuch, Schwartz, \& Davidov, 2015). The importance of specific values can change over time as a part of psychosocial development during childhood and adolescence. Hierarchies of values stabilize at the age of adolescence and change quite little in adulthood and stay as relatively stable key element of personal and ethnic identity (Sagiv, Roccas, Cieciuch, \& Schwartz 2017).

The research also proves that the relationship between ethnic values and behavior among the believers as more pronounced than among atheists (Yang, Liang, Quan, Jiang, Yu, Zheng, 2019), as well as indicate to the influence of religion on ethnic values (Winaja, Prabawa, \& Pertiwi, 2019; Devos, Spimi, \& Schwartc, 2002). In psychology, there are two approaches towards the study of values. These approaches are known as Rokeach and the Schwartz's traditions. Rokeach divides the list of 36 values into two groups. One of them includes instrumental values, and the second - terminal ones. The life goals of a person are associated with terminal values. Instrumental values allow one to achieve these goals, so they are more susceptible to changes than terminal values (Rokeach, 1973). After a detailed analyses of this classification, D. Karp wrote that, on one hand, one of the advantages of the study carried out by Rokeach, is that it is a fairly simple tool that can be used by the researchers in variety of contexts. But, on the other hand, the assumption values influence one's behavior directly, does not appear anywhere in these studies. Therefore, Karp concludes, that the relationship either do not exist, or there are several links in a long chain of causes that interfere with the relationship between those two important variables (Karp, 2020).

S. Schwartz proposed a different concept of classification of values. According to his point of view, all values could be located within one system, where values relate to the dichotomy "Conservatism and Openness to the world" that are located along one axis, and values related to the dichotomy "Your interests and the interests and well-being of other people" that are located on the second axis. The theory of Schwartz's refers to structural theories by assuming 
that if a person prefers values that are located at one pole of the dichotomy, he/she simultaneously rejects values that are at the other pole of the same dichotomy (Schwartz, 1992). D. Karp wrote that the research tool designed by S. Schwartz allows to predict the political behavior of an individual (Karp, 2020).

Thus, the sequence of shifts in theoretical paradigms in the study of values can be represented by the following diagram:

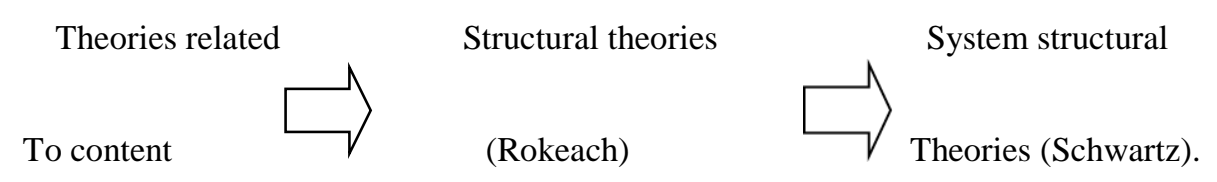

Figure 1 Paradigms in the Study of Value

\section{Research on the Relationship between Values and Ethnicity in Modern Psychology}

Values play the key aspect of one's self-esteem. As such, they are associated with and are reflected in aspects of personal and social identity of individuals (Sagiv, Roccas, Cieciuch, \& Schwartz, 2017). The concept of ethnicity in modern psychology includes two aspects: ethnic origin and ethnic identity. The first is determined by the ethnic origin of parents. The second is determined by the internal acceptance of oneself as a representative of a certain ethnic group. This acceptance depends on a socio-historical context. Therefore, as L. Kiang wrote, ethnic identity is a social construct that is dynamic in its nature (Kiang, 2014).

A number of studies point to the connection that exist between ethnicity and ethnic values in modern psychology, leading to two main directions. On the one hand, researchers are trying to determine those values that serve as the existential basis explaining the existence of people. At the same time, this is assumed that an unformed ethnic identity can lead to an individual's orientation towards other values that are not characteristic to a given ethnos (Durovic, 2008). On the other hand, how can information about ethnic values be used for practical and marketing purposes?

The researchers who represent first approach, wrote about the relationship of values and a genetic heritage and the impact of various social environments on one's values such as family, education system and a social environment as a whole (Sagiv, Roccas, Cieciuch, \& Schwartz, 2017; Jakupova, Perlenbetov, Ilimkhanovac, \& Telebayev, 2012).

The researchers who have studied Asian values, namely, D. Iwamoto and W. Liu, wrote that the most important Asian values such as collectivism, conformity to norms, respect for authority, emotional self-control, family recognition through achievement, humility, hierarchical relationships and 
Makarevičs \& Iliško, 2021. Manifestation of Ethnicity and Values:

the Case Study from the Eastern Latvia

avoidance of shame, determine the purpose of life for the representatives of Asia (Iwamoto \& Liu, 2010).

As T. Kirby and others indicate, a special place in the list of ethnic values is occupied by a value of ethnic space. Ethnic space is a place where representatives of one or similar ethnic groups form their ethnic identity in the interpersonal communication and interaction with other assimilate ethnic values. As the authors discuss, the creation of such ethnic spaces is particularly important for ethnic minorities, whose representatives strengthen their self-esteem and gain selfconfidence as a result of such communication (Kirby, Tabak, Ilac, \& Cheryan, 2020). The second direction in the research can be illustrated by the group of authors, who studied the choice of the Singaporean women in selling cosmetics in relation to those values (Koubaa, Ulvoas, \& Chew, 2011).

We propose the following definition of ethnic values: ethnic values are collective conceptions of what is considered good, desirable, and proper or bad, undesirable, and improper in ethnic and world culture.

\section{Research Methodology}

The research methodology was based on views of representatives of the content approach towards values, as well as the point of view of Schwartz and his colleagues about the place of values in the structure of motives that affect the behavior of an individual, and the connection between values and ethnic identity (Cieciuch, Schwartz, Davidov, 2015; Sagiv, Roccas, Cieciuch, Schwartz, 2017; Schwartz, 1992).

In the questionnaire offered to the research participants, consisted of three items and the participants had to assess the place of values in the structure of ethnic identity of their ethnic group. Family, religion and friendship values were assessed in a five-point scale. Five points meant that the value is very important, and value of one is not significant. In addition, each subject could supplement this list with those values that, in their opinion, are significant for their ethnos.

In total, sixty-one participants took part in this study. Taking into account the peculiarities of the particular region, where the main factor that influence the formation of ethnic identity is language, both groups of respondents were divided into the groups whose mother language was Latvian and the respondents from the other group who hold Russian as their mother tongue. The first group consisted of 26 research participants ( 20 men and 6 women), and the second - 34 ( 27 women and 7 men) participants. This was also required to indicate one's age and religion. The study excluded individuals who had two native languages: Russian and Latvian (5 people). 


\section{Research Results and Discussion}

The aim of this study was to explore the degree of importance of values of family, religion and friendship as chosen by the participants as they make sense for two ethnic groups united. The study focuses on the influence of religious affiliation of individuals on these values, the age characteristics on one's orientation towards the indicated values. Table 1 display the results of the study. The table reflects the assessments of values by the respondents

Table 1 Respondents' Assessments of Values (Mean)

\begin{tabular}{|l|l|l|l|l|}
\hline VALUES & $\begin{array}{c}\text { The group of } \\
\text { respondents with } \\
\text { the Latvian } \\
\text { language as a } \\
\text { native language }\end{array}$ & $\begin{array}{c}\text { The group of } \\
\text { respondents with } \\
\text { the Russian } \\
\text { language as a } \\
\text { native language }\end{array}$ & $\begin{array}{l}\text { Mann-Whitney } \\
\text { U test }\end{array}$ & $\begin{array}{l}\text { Statistical } \\
\text { significance }\end{array}$ \\
\hline Family & 4.1 & 4.2 & 292.5 & No \\
\hline Religious & 3.4 & 3.6 & 308 & No \\
\hline Friendship & 3.4 & 4.4 & 98.5 & $\begin{array}{l}\text { True at the } \\
\text { significance } \\
\text { level of } 0.01\end{array}$ \\
\hline
\end{tabular}

The table shows that for the first and the second group the most significant are family values. The biggest differences were found for the value of friendship. The group with the native Russian language evaluates it significantly higher than the group with the Latvian as native language. The group consists of nine nonbelievers. In the group of respondents with the Russian as a native language, the distribution by religious preferences is the following: Catholics - 6, Lutheran-1, Orthodox believers - 13, Old Believers - 12, nonbelievers - 4. The Latvian language speaking group consisted mainly of Catholics. The Russian-speaking group was dominated by the Orthodox and Old Believers. Within each group, the average values of the respondents' can be identified by assessing the significance of values for their ethnic group (for each religion). The average scores were compared with each other. The Mann-Whitney U test was used to determine statistical differences. For the family values, only one statistically significant difference was found (see Table 2). 
Makarevičs \& Iliško, 2021. Manifestation of Ethnicity and Values:

the Case Study from the Eastern Latvia

Table 2 The Assessment of the Importance of Family Values by the Representatives of the Russian Speaking Catholics and Orthodox Believers

\begin{tabular}{|l|c|c|c|l|}
\hline Values & Catholics & Orthodox & $\begin{array}{l}\text { Mann-Whitney } \\
\text { U test }\end{array}$ & $\begin{array}{l}\text { Statistical } \\
\text { significance }\end{array}$ \\
\hline Family & 4.7 & 3.8 & 17 & $\begin{array}{l}\text { True at the level } \\
\text { of significance } \\
0.05\end{array}$ \\
\hline
\end{tabular}

In the Russian-speaking group, the family values were more important for the Catholics as compared with the Orthodox Christians. In regards to religious values, two significant differences were found. They are seen in Table 3.

Table 3 Differences in the Assessment of Religious Values by Representatives of Different Religious Denominations

\begin{tabular}{|c|c|c|c|}
\hline Groups & Average rating & $\begin{array}{c}\text { Mann-Whitney U } \\
\text { test }\end{array}$ & $\begin{array}{c}\text { Statistical } \\
\text { significance }\end{array}$ \\
\hline $\begin{array}{c}\text { Catholics (Latvians)- } \\
\text { Catholics (Russians) }\end{array}$ & $3.3 / 3.8$ & 33.5 & $\begin{array}{c}\text { True at a } \\
\text { significance level of } \\
0.05\end{array}$ \\
\hline $\begin{array}{c}\text { Orthodox (Russians) } \\
\text { Non-believers } \\
\text { (Russians) }\end{array}$ & $3.8 / 2.5$ & 10 & $\begin{array}{c}\text { True at a } \\
\text { significance level of } \\
0.05\end{array}$ \\
\hline
\end{tabular}

Catholics, whose native language is Russian, consider religious values as more important for their ethnic groups as compared to the Latvian-speaking Catholics. This is typical for the Russian-speaking group to evaluate religious values as more significant for their ethnic groups as compared to non-believers. As this is seen in Table 4, statistically significant differences are found in the assessments of the value of friendship and its significance for the ethnic group.

Table 4 Differences in the Assessment of Values of Friendship by the Representatives of Different Religious Denominations

\begin{tabular}{|l|c|c|l|}
\hline \multicolumn{1}{|c|}{ Groups } & Average value & $\begin{array}{c}\text { Mann-Whitney U } \\
\text { test }\end{array}$ & \multicolumn{1}{|c|}{$\begin{array}{c}\text { Statistical } \\
\text { significance }\end{array}$} \\
\hline $\begin{array}{l}\text { Catholics (Russians) } \\
\text { Non-believers } \\
\text { (Russians) }\end{array}$ & $3.7 / 5.0$ & 2 & $\begin{array}{l}\text { True at a } \\
\text { significance level of } \\
0.05\end{array}$ \\
\hline $\begin{array}{l}\text { Non-believers } \\
\text { (Latvians)- } \\
\begin{array}{l}\text { неверующие } \\
\text { (Russians) }\end{array}\end{array} \quad 3.1 / 5.0$ & 3 & $\begin{array}{l}\text { True at a } \\
\text { significance level of } \\
0.05\end{array}$ \\
\hline
\end{tabular}


Table 4 indicates that the highest assessment of the importance of the value of friendship for their ethnic groups was presented by the Russian-speaking nonbelievers. At the same time, statistically significant differences in the assessment of values were acknowledged between the group of the Russian-speaking nonbelievers and the groups of Russian-speaking Catholics and the Latvian-speaking non-believers.

The authors have also explored the effect of age on the respondents' assessments of the significance of these values. In each language group, the participants were 30 years old and older. No statistical differences were found here. Among the added values in the Latvian-speaking group, the most frequently mentioned values were hospitality, perseverance, striving for order, adherence to traditions and tolerance to other things. The representatives of the Russianspeaking group most often have mentioned such values as hospitality, openness, and love of literature.

In conclusion, this can be stated that the respondents who belong to different ethnic groups are close in their assessments in regards to the importance of family and religious values for their ethnic groups. The exception was value of friendship, the importance of which was highly appreciated by the representatives of Russian-speaking group. Perhaps this is due to the peculiarities of the cultural and historical development of various ethnic groups and the degree of involvement in the processes of globalization.

At the same time, small groups were distinguished in groups that have different opinion about values from the general group. In the Russian-speaking group, Catholics and non-believers turned out to be such groups. Moreover, the last statement needs to be verified due to a small number of individuals belonging to this subgroup. No significant differences were found in the assessments of values by the individuals from different age categories.

\section{Conclusion}

No statistically significant differences were found in the assessments of family and religious values by subjects from the Latvian-speaking and Russianspeaking groups. Russian-speaking respondents assessed that values of friendship are higher than among the Latvian-speaking ones. The Russian-speaking Catholics value family higher than the Russian-speaking Orthodox.

The Russian-speaking Catholics rate religious values higher than the Latvian-speaking Catholics, and Russian-speaking Orthodox Christians evaluate religious values higher than Russian-speaking non-believers. The Russianspeaking non-believers evaluate values of friendship higher than the Russianspeaking Catholics and the Latvian-speaking non-believers. 
Makarevičs \& Iliško, 2021. Manifestation of Ethnicity and Values:

the Case Study from the Eastern Latvia

It should be noted that the samples concerning the religious affiliation of respondents turned out to be small in number. Therefore, these statements apply only to this sample and cannot be applied to the entire region. In the age groups under 30 and after 30 years, no statistically significant differences in the assessments of these values were found.

The study confirmed the hypotheses of $\mathrm{D}$. Iwamoto and $\mathrm{W}$. Liu that peoples living nearby for a long time develop similar ethnic values.

\section{References}

Anýžová, P. (2017). The social-psychological context of human values: The reciprocal relationship between personality traits and value orientations. Sociologický časopis/ Czech Sociological Review, 53(3), 393-426. doi.org/10.13060/00380288.2017.53.3.337

Cieciuch, J., Schwartz, S.H., \& Davidov, E. (2015). Values, social psychology. In James. D. Wright. International Encyclopedia of the Social \&Behavioral Sciences, ( $2^{\text {nd }}$ edition), 25, 41-46.

De Oliveira, D., Pankalla, A., \& Cabetinhas, R. (2012). Ethnic identity as predictor for the wellbeing: An exploratory transcultural study in Brazil and Europe. SUMMA psicologica UST 9(2), 33-42.

Devos, T., Spimi, D., \& Schwartc, S. (2002). Conflicts among human values and trust in institution. British Journal of Social Psychology, 41, 481-494.

Durovic, J. (2008). Intercultural Communication and Ethnic Identity. Journal of Intercultural Communication, 16. Retrieved from http://www.immi.se/intercultural/nr16/durovic.htm

Iwamoto, D.K., \& Liu, W.M. (2010). The impact of racial identity, ethnic identity, Asian values and race-related stress on Asian Americans and Asian International College Students' psychological well-being. Journal of Counseling Psychology,57(1), 79-91. doi: $10.1037 / \mathrm{a} 0017393$

Jakupova, S. M., Perlenbetov , M.A., Ilimkhanovac, L.S., \& Telebayev, G.T. (2012). Cultural values as an indicator of inter-ethnic harmony in multicultural societies. Procedia - Social and Behavioral Sciences, 69, 114 - 123. doi: 10.1016/j.sbspro.2012.11.390

Jugert, Ph., \& Titzmann, P. F. (2020). Developmental tasks and immigrant adolescent's adaptation. In D. Güngör, \& D. Strohmeier (Eds.). Contextualizing immigrant and refugee resilience: Cultural and acculturation perspectives (pp. 33-50). Springer International Publishing. doi: 10.1007/978-3-030-42303-2. Retrieved from: https://www.researchgate.net/publication/331258076_Developmental_Tasks_and_Immi grant_Adolescent\%27s_Adaptation

Karp, D.R. (2020). Values theory and research. Retrieved from https://what-whenhow.com/sociology/values-theory-and-research/

Kiang, L. (2014). Ethnicity and ethnic identity in context on Gjerde. Human Development, 57, 213-221. doi: 10.1159/000363399.

Kirby, T.A., Tabak, J.A., Ilac, M., \& Cheryan, S. (2020). The symbolic value of ethnic spaces. Social Psychological and Personality Science, 867-878.

Kluckhohn, C. (1951). Values and value-orientations in the theory of action: An exploration in definition and classification, In Parsons, T., \& E. Shils (Eds.), Toward a general theory of action, (pp.388 - 433). Cambridge, MA: Harvard University Press. 
Koubaa, Y., Ulvoas, G., \& Chew, P. (2011). The dual impact of traditional and national cultural values on expatriate ethnic groups' attitudes and willingness to buy. Asia Pacific Journal of Marketing and Logistics, 23(5), 626-640.

Meeussen, L., Agneessens, F., Delvaux, E., \& Phalet, K. (2018). Ethnic diversity and value sharing: A longitudinal social network perspective on interactive group processes. British Journal of Social Psychology, 57, 428-447.

Rokeach, M. (1973). The nature of human values. New York: The Free Press.

Sagiv, L., Roccas, S., Cieciuch, J., \& Schwartz, S. (2017). Personal values in human life. Nature Human Behavior, 1, 630-639.

Schwartz, S. H. (1992). Universals in the content and structure of values: Theoretical advances and empirical tests in 20 Countries. Advances in Experimental Social Psychology, 25, 1-65

Winaja, W.I, Prabawa, W.S.W., \& Pertiwi, P.R. (2019). Acculturation and its effects on the religious and ethnic values of Bali's Catur village community. Journal of Social Studies Education Research, 10(3), 249-275.

Yang, Y., Liang, F., Quan, F., Jiang, G., Yu, K., \& Zheng, Y. (2019). The importance of ethnicity: Developing a measure of minority ethnic value and value-expressive behavior among Chinese ethnic minorities, Frontiers in Psychology, 19, doi.org/10.3389/fpsyg.2019.02603. Retrieved from https://www.frontiersin.org/articles/ 10.3389/fpsyg.2019.02603/full 